\title{
South American Cucurbit Fruit Fly, Anastrepha grandis (Macquart) (Insecta: Diptera: Tephritidae) ${ }^{1}$
}

H. V. Weems, Jr. ${ }^{2}$

\section{Introduction}

Anastrepha grandis (Macquart) (1846: 227), which exists in several South American countries and possibly Panama, attacks watermelon and other fruits of the family Cucurbitaceae. Once a pest of minor to moderate importance generally, in recent years it has become a rather important pest. The pest status differs in each country and has changed in the last decade. This species would seem to be potentially of economic importance in Florida and southern Texas should it ever be introduced there. It has been intercepted in the United States in pumpkin from Argentina and Brazil, and one adult was found in banana debris from Panama.

\section{Synonymy}

Acrotoxa grandis (Macquart)

Anastrepha schineri Hendel

Anastrepha latifasciata Hering

Tephritis grandis Macquart
Trypeta grandis (Macquart)

\section{Distribution}

Argentina, Bolivia, Brazil (except north), Colombia, Ecuador, Panama (?), Paraguay, Peru and Venezuela.

\section{Identification}

Rather large, yellow-brown, with yellow and dark-brown markings. Mesonotum 3.3 to $4.0 \mathrm{~mm}$ long, yellow-brown, with humerus, median stripe widening to include acrostichal bristles but not reaching scutellum, lateral stripes from just before transverse suture to side of scutellum, stripe below notopleuron, metapleuron, and scutellum except extreme base yellow; a sublateral stripe from level of humeral bristle to scutellum, broken at transverse suture, a band along scutoscutellar suture, intensified medially, and a spot on pteropleuron dark brown; metanotum blackened laterally. Macrochaetae dark brown; pile yellowish brown. No sternopleural bristle. Wing 9.0 to $10.5 \mathrm{~mm}$ long, the bands yellow brown, rather diffuse; costal and $\mathrm{S}$ bands broadly connected, and no distinct hyaline spot anterior to

1. This document is EENY-205 (originally published as DPI Entomology Circular 334), one of a series of Featured Creatures from the Entomology and Nematology Department, Florida Cooperative Extension Service, Institute of Food and Agricultural Sciences, University of Florida. Published: March 2001. This document is also available on Featured Creatures Website at http://creatures.ifas.ufl.edu. Please visit the EDIS Website at http://edis.ifas.ufl.edu and the Entomology and Nematology Department website at http://entnemdept.ifas.ufl.edu/.

2. H. V. Weems, Jr., Florida Department of Agriculture and Consumer Services, Division of Plant Industry, Gainesville, FL.

The Institute of Food and Agricultural Sciences (IFAS) is an Equal Employment Opportunity - Affirmative Action Employer authorized to provide research, educational information and other services only to individuals and institutions that function without regard to race, creed, color, religion, age, disability, sex, sexual orientation, marital status, national origin, political opinions or affiliations. For information on obtaining other extension publications, contact your county Cooperative Extension Service office. Florida Cooperative Extension Service / Institute of Food and Agricultural Sciences / University of Florida / Larry R. Arrington, Interim Dean 
vein $\mathrm{R}_{4+5}$; distal arm of $\mathrm{V}$ band absent, the proximal arm not joining $S$ band.

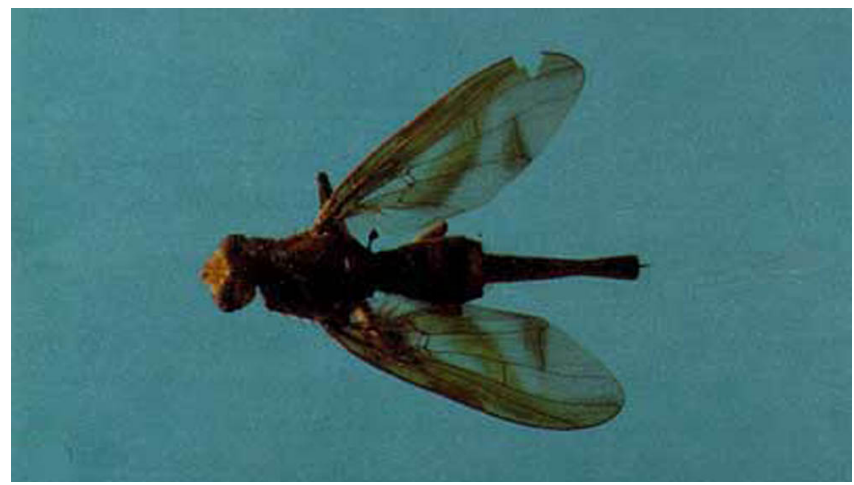

Figure 1. Adult female South American cucurbit fruit fly, Anastrepha grandis (Macquart). Credits: Division of Plant Industry

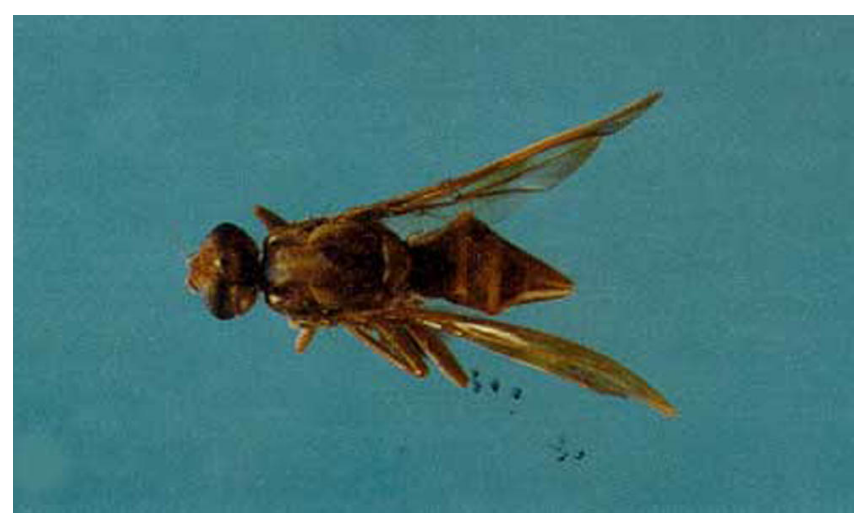

Figure 2. Adult male South American cucurbit fruit fly, Anastrepha grandis (Macquart). Credits: Division of Plant Industry

Female terminalia: Ovipositor sheath 5.8-6.2 mm long, tapering posteriorly to apical third, which is distinctly depressed and broadened; in profile the sheath is distinctly concave dorsally on median half and concave ventrally on apical third. Rasper well developed, of slender, curved hooks in five or six rows. Ovipositor slightly longer than length of ovipositor sheath, being somewhat curved dorsoventrally to permit fitting into sheath; tip long and slender, without serrations; extreme base slightly widened (Stone 1942).

Steyskal (1977) distinguished A. grandis from the other four species of the Grandis group as follows: Vein $\mathrm{R}_{3}$ somewhat undulant; metanotum yellow (A. bezzii Lima and A. balloui Stone); vein $\mathrm{R}_{3}$, not undulant; metanotum marked with black ( $A$. artrigona Hendel, A. shannoni Stone, and A. grandis (Macquart)). Mesonotum not striped with black ( $A$.

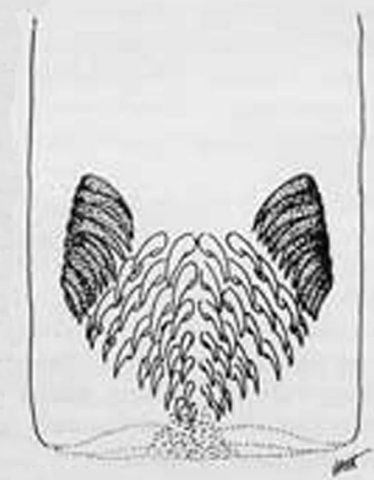

Figure 3. Rasters at tip of ovipositor sheath. Credits: Division of Plant Industry

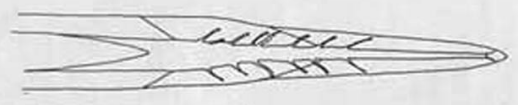

Figure 4. Ovipositor. Credits: Division of Plant Industry

atrigona); mesoscutum with black stripes ( $A$. shannoni and A. grandis). Mesoscutum and pleura largely black, wing with pattern darkened ( $A$. shannoni); mesoscutum and pleura with little black, wing pattern very little darkened (A. grandis).

\section{Hosts}

Citrullus lanatus (Thunberg) Matsumura \& Nakai (watermelon), Cucumis sativus Linnaeus (cucumber), Cucurbita maxima Duchesne (autumn and winter squash, pumpkin), Cucurbita pepo Linnaeus (summer and autumn pumpkin and squash, gourd, marrow), Cucurbota moschata (Duchesne ex Lam.) Duchesne ex Poiret ("amyama," "pumpkin"), Lagenaria siceraria (Molina) Standl. ("camasa"), Cucumis melo L. ("honeydew melon"). It has also been known to attack common guava, Psidium guajava (Norrbom in press) The record of rearing from oranges (Greene 1934) is erroneous. Immature fruits of cucurbits apparently are preferred, but mature or nearly mature fruits of some varieties are attacked occasionally.

\section{Survey and Detection}

Adults are easily recognized by their very large size (wing length $10 \mathrm{~mm}$ ), long aculeus (a sharp spine jutting from beneath the margin of the eight sternite) and rather diffuse wing markings which are not of the typical Anastepha type. 
Larvae can be collected from infested fruit and are very difficult to identify to species except when reared to adults. For best larval preservation, kill in boiling water, place in $50 \%$ isopropyl alcohol for two days, then in $75 \%$ isopropyl alcohol. Adults may be collected on stickyboard and in baited traps.

\section{Selected References}

Enkerlin, Dieter, Laura Garcia R., and Fidel Lopez M. 1989. p. 83-90. In Robinson, A.S., and G. Hooper (eds.), Fruit flies, Their Biology, Natural Enemies and Control. 3A: I-xii, 1-372.

Foote, R.H. 1967. Family Tephritidae. In Vanzolini, M. (ed.), A Catalogue of the Diptera of the Americas South of the United States. 57: 1-91. Dept. Zool., Sec. Agric., São Paulo, Brazil.

Greene, C.T. 1934. A revision of the genus Anastrepha based on a study of the wings and on the length of the ovipositor sheath (Diptera: Trypetidae). Proceedings of the Entomological Society of Washington 36: 127-179.

Macquart, J. 1846. Diptères exotiques nouveaux ou peu connus. (1845) (1844): 133-364, illus. Mém. Soc. Roy. Sci., Agric., Arts Lille. (published separately as Supplément I, p. 5-238.

Norrbom, A.L. (31 October 2001). Anastrepha grandis (Macquart). The Diptera site. http://www.sel.barc.usda.gov/diptera/tephriti/ Anastrep/grandis.htm (14 January 2002).

Norrbom, A.L. Host plant database for Anastrepha and Toxotrypana (Diptera: Tephritidae: Toxotrypanini). Diptera Data Dissemination Disk 2. (in press).

Steyskal, G.C. 1977. Pictorial key to species of the genus Anastrepha (Diptera: Tephritidae). (Spec. publ.) Entomological Society of Washington. 35 p.

Stone, Alan. 1942. The fruitflies of the genus Anastrepha. U.S. Department of Agriculture Miscellaneous Publication No. 439, Washington, DC. $112 \mathrm{p}$.

White, I.M., and M.M. Elson-Harris. 1994. Fruit Flies of Economic Significance: Their Identification and Bionomics. CAB International. Oxon, UK. 601 p. 